\title{
Lamins in Lung Cancer: Biomarkers and Key Factors for Disease Progression through miR-9 Regulation?
}

\author{
Julien Guinde ${ }^{1,2}{ }$, Diane Frankel ${ }^{3}$ (i) , Sophie Perrin ${ }^{1,4}$ (D), Valérie Delecourt ${ }^{1}$, Nicolas Lévy ${ }^{5}$, \\ Fabrice Barlesi ${ }^{6}$, Philippe Astoul ${ }^{2}$ (D), Patrice Roll ${ }^{3}$ and Elise Kaspi ${ }^{3, *}$ (D) \\ 1 Aix Marseille Université, INSERM, MMG, 13385 Marseille, France; julien.guinde@ap-hm.fr (J.G.); \\ sophie.perrin@univ-amu.fr (S.P.); valeriedelecourt22@gmail.com (V.D.) \\ 2 APHM, Hôpital Nord, Department of Thoracic Oncology-Pleural Diseases—Interventional Pulmonology, \\ CEDEX 5, 13385 Marseille, France; pastoul@ap-hm.fr \\ 3 Aix Marseille Université, APHM, INSERM, MMG, Hôpital la Timone, Service de Biologie Cellulaire, \\ 13385 Marseille, France; diane.frankel@univ-amu.fr (D.F.); patrice.roll@univ-amu.fr (P.R.) \\ 4 ProGeLife, 13385 Marseille, France \\ 5 Aix Marseille Université, APHM, INSERM, MMG, Hôpital la Timone, Département de Génétique Médicale, \\ 13385 Marseille, France; nicolas.levy@univ-amu.fr \\ 6 Aix Marseille Université, APHM, CNRS, INSERM, CRCM, Multidisciplinary Oncology \& Therapeutic \\ Innovations Department, 13385 Marseille, France; fabrice.barlesi@ap-hm.fr \\ * Correspondence: elise.kaspi@univ-amu.fr; Tel.: +33-491-324-934; Fax: +33-33-491-804-319
}

Received: 13 June 2018; Accepted: 9 July 2018; Published: 16 July 2018

\begin{abstract}
Lung cancer represents the primary cause of cancer death in the world. Malignant cells identification and characterization are crucial for the diagnosis and management of patients with primary or metastatic cancers. In this context, the identification of new biomarkers is essential to improve the differential diagnosis between cancer subtypes, to select the most appropriate therapy, and to establish prognostic correlations. Nuclear abnormalities are hallmarks of carcinoma cells and are used as cytological diagnostic criteria of malignancy. Lamins (divided into A- and B-types) are localized in the nuclear matrix comprising nuclear lamina, where they act as scaffolding protein, involved in many nuclear functions, with regulatory effects on the cell cycle and differentiation, senescence and apoptosis. Previous studies have suggested that lamins are involved in tumor development and progression with opposite results concerning their prognostic role. This review provides an overview of lamins expression in lung cancer and the relevance of these findings for disease diagnosis and prognosis. Furthermore, we discuss the link between A-type lamins expression in lung carcinoma cells and nuclear deformability, epithelial to mesenchymal transition, and metastatic potential, and which mechanisms could regulate A-type lamins expression in lung cancer, such as the microRNA miR-9.
\end{abstract}

Keywords: lamins; lung cancer; lung adenocarcinoma; microRNAs; miR-9

\section{Introduction}

Lung cancer is one of the most frequent cancers and the leading cause of cancer-related mortality in developed countries [1,2]. Among non-small cell lung cancer (NSCLC), adenocarcinoma represents the most frequent histological type. The European Society for Medical Oncology (ESMO) recommends molecular profiling of lung adenocarcinoma cells to select targeted therapy. This characterization comprises epidermal growth factor receptor (EGFR), V-Ki-ras2 Kirsten rat sarcoma viral oncogene homologue (KRAS), v-Raf murine sarcoma viral oncogene homologue B1 (BRAF), human epidermal growth factor receptor 2 (HER2) mutation profiles, together with anaplastic lymphoma kinase (ALK) and C-ros oncogene 1 (ROS1) rearrangement, and $c-M E T$ amplification [3,4]. A genetic alteration 
is found in approximately $50 \%$ of the patients with lung adenocarcinoma [5]. Despite advances in treatment during the last decade (such as chemotherapy, tyrosine kinase inhibitors or immunotherapy), the prognosis of advanced stages of NSCLC still remains poor. In this context, understanding which factors are involved in the metastatic process is a major issue, in order to identify new biomarkers and to develop new therapeutic strategies.

Morphological changes in the size and shape of the nucleus, which are frequently observed in carcinoma cells [6,7], are commonly used as cytological diagnostic criteria of malignancy [8]. These nuclear abnormalities are probably the cause or the consequence of proteins modifications entering in the constitution of the nuclear matrix and/or the nuclear envelope (NE). The NE includes an inner and an outer nuclear membrane (INM, ONM), and is interrupted by nuclear pores implicated in nucleocytoplasmic exchanges. A family of type $\mathrm{V}$ intermediate filaments proteins called 'lamins' is one of the main components of the nuclear matrix, including the nuclear lamina, which is a network of lamin filaments located underneath the INM. Lamins confer capacity of resistance in cellular deformability [8-10]. They also regulate chromatin organization, DNA replication, DNA repair, transcription, differentiation [11-13], and apoptosis [14]. Lamins are known to interact with cytoskeleton through INM SUN proteins inside the LINC (LInker of Nucleoskeleton and Cytoskeleton) complex and are crucial for mechanotransduction and mechanical stability [9,15]. Lamins are divided into A-type and B-type. Two major isoforms of A-type lamins (lamin A and lamin C, referred as lamin $\mathrm{A} / \mathrm{C}$ ) and two minor isoforms (lamin A delta 10 and lamin $\mathrm{C} 2$ ) are alternative splice variants of LMNA [16,17], while lamin B1 is encoded by LMNB1, and lamins B2 and B3 result from an alternative splicing of $L M N B 2$ [18].

Lamins proteins are composed of a central helicoid domain surrounded by tow globular parts in N- or C-terminal. The C terminal tail bears an NLS region as well as an immunoglobulin-like domain $[19,20]$. Whereas lamin $C$ is directly produced as a mature protein, lamins A, B1, and B2 are generated as precursors called 'prelamins' that undergo 3 (lamin A) or 4 (B-type lamins) steps of maturation. These processes occur though the CaaX motif in C-terminal that is specific for each precursor. Lamins A, B1, and B2 share common first steps of maturation. As a start, a farnesyl group (15-carbon hydrophobic group) is added to the cysteine residue of the CaaX box. This phenomenon leads to the anchorage of these prelamins to the endoplasmic reticulum membrane or to the outer nuclear envelope. The 'aaX' amino acids are then cleaved by ZMPSTE24/FACE1 or Rce1/FACE2 proteases. As a third step, the cysteine residue goes through methylation performed by an isoprenylcysteine carboxymethyl transferase (ICMT). At that point, B-type lamins are mature, whereas prelamin A needs to experience a last maturation step. Indeed, ZMPSTE24/FACE1 removes the last 15 amino acids of the precursor leading to the release of a mature non farnesylated protein. Therefore, while B-type lamins remain attached to the nuclear envelope thanks to their farnesyl anchor where they participate to the composition of nuclear lamina, lamin A and lamin C are localized simultaneously to the lamina and the rest of nuclear matrix [8,21-23].

Among the lamins subtypes, B-type lamins have a ubiquitous expression and are considered essential for cell survival. The expression of A-type lamins, however, appears to be related to the state of cellular differentiation. They are generally expressed in well-differentiated cells, while undifferentiated cells or embryonic cells do not show detectable levels of A-type lamins [24-28]. Moreover, the proportion of A-type and B-type lamins in cells may vary depending on tissues, in relation with their elasticity $[29,30]$.

Interestingly, mutations of lamins or partners' genes cause a heterogeneous landscape of disease clustered under the name 'laminopathies' (http:/ / www.umd.be/LMNA/) in which some of them are characterized by premature aging features [31]. As example, the Hutchinson-Gilford's Progeria Syndrome (HGPS) is a premature aging syndrome mainly caused by the p.G608G mutation in LMNA exon 11 firstly described in 2003 [32]. This mutation leads to a deletion of 50 amino acids on prelamin A, including the cleavage site of FACE1/ZMPSTE24 protease, resulting in the abnormal persistence of a C-terminal farnesylated cysteine at the end of the maturation processing $[32,33]$. This abnormal 
protein, called 'progerin', remains thus anchored in the INM, generating nuclear abnormalities and severe nuclear dysfunctions leading to a premature senescence. Patients die prematurely (mean age 14.6 years) usually from cardiovascular complications. Attractively, whereas other premature aging diseases present cancer predisposition based on the failure of their DNA repair systems (bloom syndrome/xeroderma pigmentusom), HGPS patients do not exhibit such susceptibilities [34]. Furthermore, Fernandez and collaborators recently identified a tumor-protective function of BRD4 by studying HGPS model [35]. Thus, accumulation of abnormal persistent farnylated truncated prelamin A combine with other factors could prevent oncogenic development in these patients.

Additionally, previous studies have hypothesized that lamins are involved in the development and progression of tumors. Few studies highlighted B-type lamins variation at a protein level, without a link to prognosis. In contrast, several studies suggested that A-type lamins are involved in the development and progression of cancers (Table 1) [36]. Variations of localization or level of expression of lamin A and/or C were reported in several histological types. As described in Table 1, a decrease of A-type lamins expression was found in breast cancers, prostate, colon, ovary, gastric, or endometrial, associated with a poor prognosis, leading to decreased overall survival, increase of metastatic sites number, tumor aggressiveness, or disease recurrence [37-42]. Conversely, some studies identified a link between the increase of A-type lamins expression and the progression of the colorectal, prostate, and ovarian cancer [43-45]. In these cancers, an enhanced expression of A-type lamins was associated with higher stage tumors or a decreased overall survival (Table 1). These results showed that the role of lamins $\mathrm{A}$ and $\mathrm{C}$ is probably dependent of the context and cancer type and requires other studies to identify their role in the progression of cancer, according to the histological type, the mutational profile and the stage of the underlying disease.

In this review, we discuss lamins expression variations in lung cancer, the impact of these findings for disease diagnosis and prognosis and which mechanisms could regulate A-type lamins expression in lung cancer, such as the microRNA miR-9.

Table 1. Summary of A-type Lamins expression (at a protein level) depending on tumor type and link with the prognostic value.

\begin{tabular}{|c|c|c|c|}
\hline Cancer/Tumor Type & A-Type Lamins Expression & Prognostic Value & References \\
\hline Gastric carcinoma & $\begin{array}{c}\text { Decrease } \\
\text { Cytoplasmic localization }\end{array}$ & Decreased overall survival & $\begin{array}{l}\text { Wu et al., J. Exp. Clin. Cancer } \\
\text { Res. } 2009 \\
\text { Moss et al., Gut } 1999\end{array}$ \\
\hline Breast carcinoma & Decrease & Decreased overall survival & $\begin{array}{l}\text { Capo-Chichi et al., Chin. J. } \\
\text { Cancer } 2011\end{array}$ \\
\hline Ovarian carcinoma & $\begin{array}{c}\text { Increase } \\
\text { Isolated decrease of lamin A }\end{array}$ & $\begin{array}{c}\text { Higher stage tumours } \\
\text { Decreased overall survival } \\
\text { Increased number of metastatic sites }\end{array}$ & $\begin{array}{l}\text { Wang et al., J. Proteome Res. } 2009 \\
\text { Gong et al., Pathol. Res. } \\
\text { Pract. } \mathbf{2 0 1 5}\end{array}$ \\
\hline Endometrial carcinoma & Isolated decrease of lamin A & Tumor agressiveness & Cicchillitti et al., Oncotarget 2017 \\
\hline $\begin{array}{c}\text { Prostate } \\
\text { adenocarcinoma }\end{array}$ & $\begin{array}{l}\text { Increase } \\
\text { Decrease }\end{array}$ & $\begin{array}{c}\text { Increased risk for lymph } \\
\text { node metastasis }\end{array}$ & $\begin{array}{l}\text { Kong et al., Carcinogenesis } 2012 \\
\text { Saarinen et al., PLoS ONE } 2015\end{array}$ \\
\hline Colon carcinoma & $\begin{array}{l}\text { Increase } \\
\text { Decrease }\end{array}$ & $\begin{array}{l}\text { Decreased overall survival } \\
\text { Increase of disease recurrence }\end{array}$ & $\begin{array}{l}\text { Willis et al., PLOS ONE } 2008 \\
\text { Belt et al., EJC } 2011\end{array}$ \\
\hline $\begin{array}{l}\text { Small Cell Lung } \\
\text { carcinoma }\end{array}$ & Decrease & / & $\begin{array}{l}\text { Broers et al., Adv. Exp. Med. } \\
\text { Biol. } 2014 \\
\text { Broers et al., Am. J. Pathol. } 1993 \\
\text { Kaufmann et al., Cancer } \\
\text { Res. } 1991\end{array}$ \\
\hline \multirow{2}{*}{ Lung adenocarcinoma } & Cytoplasmic localization & / & $\begin{array}{l}\text { Broers et al., Adv. Exp. Med. } \\
\text { Biol. } 2014\end{array}$ \\
\hline & Isolated decrease of lamin A & $\begin{array}{l}\text { Increased number of metastatic sites } \\
\text { Poor Performans status }\end{array}$ & Kaspi et al., PLoS ONE 2017 \\
\hline
\end{tabular}




\section{Lamins' Expression in Normal and Cancer Lung Tissues}

Only few studies were dedicated to lamins expression in the normal respiratory epithelium (bronchial and/or alveolar cells) and in lung cancer. In normal lung tissue, lamins $\mathrm{A} / \mathrm{C}$ are physiologically expressed in a subset of cells, according to their differentiation stage. In lung cancer, a wide range of A-type lamins' expression or localization has been described, without a clear relation with the prognosis.

\subsection{Physiological Lamins' Expression}

In 1997 and 2014, Broers et al. [14,27] have studied lamins' expression from normal human lung tissues. The expression of A- and B-types lamins was investigated by immunostaining on lung tissue using a panel of specific antibodies for each lamin subtypes. The A-type lamins' expression was most prominent in well-differentiated epithelial cells as these proteins were expressed in bronchial columnar cells, containing highly bronchial differentiated cells, and in pneumocytes, contrary to bronchial basal cells. These results are coherent with literature, A-type lamins being poorly expressed in non-differentiated cells.

Moreover, the authors observed that lamin B2 was expressed by all bronchial cells and alveolar pneumocytes, whereas lamin B1 expression was restricted to the bronchial basal cells and was not detected in bronchial columnar cells. Pneumocytes showed heterogeneous staining.

\subsection{Lamins' Expression Depending on Lung Cancer Histological Subtypes}

In lung cancer, only few studies were devoted to a description of lamins A, C, and B1 expression in cell lines and in human tissues. In 1990s, Kaufmann and Broers' teams showed that A-type lamins were expressed in non-small cell lung cancer (NSCLC) cell lines, but were absent or very weak in small cell lung cancer (SCLC) cell lines, with no variation of lamin B1 expression. According to Kaufmann's study, lamin A and C expression was reduced of more than $80 \%$ in SCLC cell lines compared to NSCLC cell lines, using Western and Northern Blotting [46]. Moreover, after v-ras oncogene transfection in NCI-H249 SCLC cell line, which changed the phenotype of cells from SCLC to NSCLC, a 10-fold increase in lamin A and C levels was observed, associated with higher amounts of lamins A and C mRNAs. Similar levels of lamin B were observed regardless v-ras transfection [46]. In 1993, Broers et al. [47] confirmed these findings in twenty-two human lung cancer cell lines using immunocytochemical, immunoblotting, and Northern blotting analyses. Lamins A and C were not or partly expressed in 14 out of 16 SCLC cell lines, whereas all NSCLC cell lines displayed lamins A and C expression. They also showed that B-type lamins were expressed in all SCLC and NSCLC cell lines. Moreover, analysis of 46 frozen human lung cancer biopsies showed consistent results: none or very weak lamins A and C expression was observed in $87 \%$ of SCLC cases (13/15), unlike adenocarcinoma and squamous cell carcinoma, which all presented lamins A and C expression. Interestingly, an aberrant cytoplasmic localization of A-type lamins was described rather than expected nuclear staining in several samples of adenocarcinomas. This abnormal cytoplasmic localization of A-type lamins has also been described in some colon, gastric, and pancreatic cancers [14,48]. Concerning B-type lamins' expression, all tissues from SCLC and NSCLC were positive even though some cases of lung adenocarcinoma showed a loss of their expression [47].

To go further in lamins A and C expression in lung adenocarcinoma, Machiels et al. [49] have studied their expression in three lung adenocarcinoma cell lines, using a monoclonal antibody directed against both lamins $A$ and $C$, and one antibody which specifically recognized lamin A but not lamin $C$ in immunofluorescence and immunoblotting experiments. In one cell line (GLC-A1), lamin A aggregates were observed throughout the nucleoplasm, while the nuclear lamina had a weak signal. Moreover, in this cell line, amounts of lamins $A$ and $C$ proteins, as well as mRNAs, were lower than in other cell lines and the ratio between lamin $A$ and lamin $C(A / C)$ mRNAs was $1 / 8$, instead of $1 / 1$ in other cell lines. Again, no evidence of B-type lamins expression variation was notified. 
In 2017, our team analysed lamin A, C, and B1 expression in metastatic cells of lung adenocarcinoma from pleural effusions. Interestingly, a strong decrease of lamin A, but not of lamin $\mathrm{C}$ expression was observed in a group of patients [50]. The lamin ratio [ratio = Lamin A/(Lamin A + Lamin C)] established by Western Blot led to classify the patients according to lamin A expression. This ratio was about 10 -fold reduced for about a third of patients who were thus considered as presenting a low lamin A expression. Concerning the other group of patients, lamin A expression was considered as preserved. No variation of lamin B1 or lamin C expression was observed between the two groups. Using flow cytometry, this decrease of lamin A expression was correlated with the lack of EMA (Epithelial Membran Antigen)/MUC1, an epithelial malignancy marker which is involved in the epithelial to mesenchymal transition (EMT) [51,52]. Moreover, contrary to Broers' study [14], no aberrant cytoplasmic localization of A-type lamins was found. Interestingly, the expression of lamin A was inversely correlated with the number of metastatic sites; patients with low lamin A expression had a higher number of metastases, and association of pleural, bone, and lung metastatic localization was significantly more frequent. Finally, these patients also had a higher Performans Status score compared with patients with high lamin A expression. Based on these findings, we had proposed low lamin A (with conserved lamin C) expression in pleural metastatic cells from lung adenocarcinoma as a pejorative factor associated with the development of metastasis. To our knowledge, this work is the first to investigate lamins A, C, and B1 expression as potential biomarkers in lung adenocarcinoma cells from metastatic pleural effusion. Nevertheless, the molecular mechanisms linking a reduced lamin A expression to an enhanced metastatic potential in lung adenocarcinoma are still lacking.

All together, these data suggest a preferential role of A-type lamins linked to lung cancer other the B-type lamins. Moreover, lamin A protein seems mainly affected in contrast with lamin C.

\subsection{Potential Link between the Loss of A-Type Lamins and Nuclear Deformability and Metastatic Potential Enhancement}

The factors driving differences in lamins' expression and the associated consequences with the metastatic process are still poorly understood. Within lamina, lamins indirectly interact with other proteins of the cytoskeleton, in particular with actin microfilaments. Through these interactions and connections, the stiffness properties of lamina would be transmitted via the cytoskeleton up to the plasma membrane, generating a real network of mechanic-transduction, and conferring a final link between the cell nucleus and the extracellular matrix [53]. Because the nucleus is responsible for the main properties of mechanical resistance, a decrease of its rigidity would be at the origin of a loss of the mechanisms of resistance of the cell in its entirety [54]. Several publications have emphasized the role of A-type lamins in nucleus deformability and stiffness, showing that a decrease of A-type lamins expression was associated with nuclear changes, such as an increase of the nucleus deformability and a decrease of its capacities of resistance $[10,15,55,56]$. Pajerowski et al. showed a higher nuclear deformability of embryonic stem cells, rather than more differentiated cells, depending on A-type lamins' expression [57]. More recently, Davidson et al. developed a new microfluidic device showing that A-type lamins-deficient fibroblasts exhibited increased nuclear deformability and more plastic nuclear deformations compared to wild-type fibroblasts [55]. In more detail, Lammerding et al. demonstrated that mouse embryonic fibroblasts lacking both lamins A and C, only lamin A, or only lamin B1 had severely reduced, mildly reduced, and normal nuclear stiffness, respectively, in comparison to wild type cells [10]. These consequences of lacking lamins $\mathrm{A}$ and $\mathrm{C}$ can also be illustrated at a physiological level by polynuclear neutrophils, which are highly specialized and differentiated cells having distensible multilobed nuclei which do not express A-type lamins. Their nuclear deformability allows them to migrate through narrow capillaries or small tissue opening [56].

During cancer cell invasion, tumour cells produce growth factors, angiogenic factors, matrix metalloproteases, and have to acquire mobility and deformability to migrate through spaces in extracellular matrix smaller than the size of the nucleus. To spread to other organs, cells must deform 
to migrate through very small spaces and embolize into the circulation. The cellular deformability highly depends on the nucleus, which is the largest and stiffest cellular organelle. As described above, the deformability of the nucleus is largely determined by A-type lamins' expression, and their loss confers superior deformability to cancer cells, which could facilitate migration through solid tissues and, at last, would promote the metastatic process $[58,59]$.

Concerning lung cancer, consistent results were obtained. Pajerowski et al. demonstrated that the loss of A-type lamins in lung adenocarcinoma cell line A549 enhanced their nuclear deformability compared to A549 cells expressing these lamins [57]. Moreover, A-type lamins knockdown in A549 cells induced similar compliance and deformability than adult hematopoietic stem cells. Another study confirmed the link between the nuclear deformability and a low expression of lamins A and C in lung cancer cells: indeed, Lu et al. [60] exposed A549 cells to the anti-tumour green tea extract, which was previously described to induce cell adhesion and decrease motility in these cells. Green tea extract exposition has been described to lead to a 2-fold increase of A-type lamins' expression at protein as well as mRNA levels, with a dose-related effect and thus, resulting in cell motility decrease.

All these studies demonstrate that A-type lamins are key factors involved in nuclear deformability, and the loss of lamin A only or both lamins $\mathrm{A}$ and $\mathrm{C}$ expression probably enhances metastatic potential in lung cancer. To our knowledge, only one study has made the link between the isolated reduction of lamin A expression and the enhancement of metastatic potential in patients suffering from metastatic lung adenocarcinoma [50]. However, lamins $\mathrm{A}$ and $\mathrm{C}$ are both encoded by the LMNA gene, and produced by alternative splicing resulting in two main mRNAs, the prelamin A transcript and the lamin $C$ transcript. The isolated decrease of lamin A expression could be the consequence of a regulation via splicing factors or by microRNAs (miRNAs) at the post-transcriptional level.

\section{Potential Mechanisms of A-Type Lamins Regulation in Lung Cancer Implicating miR-9}

\subsection{MicroRNAs}

MicroRNAs (also called miRNAs or miRs) are small non-coding RNAs, containing 18 to 25 nucleotides, described for the first time in 1993 in C. elegans [61]. Genes encoding miRNAs could be localized in intergenic regions in the dependence of specific promotors. Alternatively, miRNA encoding sequence could be localized in introns or exons of other genes, with a transcription being dependent of the promotor of these genes. First, a primary transcript composed of more than $1 \mathrm{~kb}$, called 'pri-miRNA', is produced by transcription using RNA polymerase II. The pri-miRNA is then cleaved by the RNase III enzyme Drosha into a smaller precursor called 'pre-miRNA' [62], containing 70 nucleotides organized in a stem-loop structure. After its exportation into the cytoplasm through the nuclear-cytoplasmic pores, the pre-miRNA undergoes a last cleavage step by the endonuclease Dicer, resulting in production of an 18-25 nucleotide-long duplex miRNA [63]. One strand of this duplex is eliminated in the RISC complex (RNA-induced silencing complex). The second strand, considered as the mature miRNA, is then able to target messengers RNAs (mRNAs). The seed region, which is defined by the nucleotides 2 to 7 in the $5^{\prime}$ region of miRNAs, settles most frequently on the $3^{\prime}$ UTR (untranslated transcript region) of the target mRNA by complementarity. This interaction leads to target mRNA degradation or more frequently to the inhibition of its translation depending on a perfect or partial hybridization, respectively [64]. Interestingly, one miRNA can bind to hundreds of target mRNAs and inversely, different miRNAs, sharing the same or almost identical seed sequence can target the same mRNA $[65,66]$. Moreover, mature miRNAs can also be re-imported into the nucleus, where they recognize promoters of target genes, and thus regulate their transcription [67]. miRNAs are since recognized as leading actors of the regulation of genic expression.

\subsection{MicroRNAs and Lung Cancer}

Several miRNAs contribute to the development and the progression of several cancers by controlling, for example, cell growth, tissue differentiation, and apoptosis. These miRNAs can function 
as tumour suppressors or oncogenes, and belong to the so called 'oncomiRs' [68]. They are also known to repress major cancer-related genes and might be considered as useful tools for diagnosis and prognosis. Finally, some of them are even considered as new therapeutic targets leading to the development of a preclinical study (NCT01829971) [69,70].

In lung cancer, many studies are descriptive, by analysing miRNA expression profile in lung tumour, in comparison to normal adjacent tissue. For some of them, a link between deregulated miRNAs and pathways was established using in silico approaches [71-73]. Moreover, the main miRNAs involved in lung cancer have newly been summarized by Uddin et al. [74]. Two recent publications [71,72] identified a miRNA expression profile, in which the five members of the miR-200 family (miR-141, miR-200a, miR-200b, miR-200c, miR-429) were up- or down-regulated in lung cancer and particularly in lung adenocarcinoma. The miR-200 family plays a major role by silencing epithelial to mesenchymal transition (EMT). EMT is characterized by the upregulation of mesenchymal markers and is associated with the down-regulation of epithelial differentiation markers, such as E-cadherin $[75,76]$. EMT is correlated with invasive tumor metastases and poor prognosis because of an increase of cell motility and invasiveness [51,52,76,77]. Thus, miR-200a/b/c are considered as tumor suppressors by repressing the mRNA translation of ZEB1 and ZEB2 transcriptional factors, leading to E-cadherin expression silencing [78]. Conversely, Tian et al. [72], described an up-regulation of these miRNAs in lung adenocarcinoma tissues. Nevertheless, this study focused on stage I lung adenocarcinoma without analyzing the metastatic potential. Concerning miR-429, its up-regulation in lung adenocarcinoma cell lines was associated with cell proliferation and cell metastasis [79]. Moreover, circulating microRNAs from liquid biopsy have been proposed as diagnostic and/or prognostic tools in lung cancer [80]. Among them, elevated serum levels of miR-141, miR-200b, and miR-429 have been proposed as potential biomarkers for early diagnosis in this context [81,82], even though elevation of these microRNAs in blood samples might not be lung specific as it has also been reported in other cancers.

\section{3. miR-9 in Lung Cancer}

Mature miR-9-5p (miR-9 as previous id) results from three miR-9 genes, named miR-9-1, -2 , and -3 , depending on their localization (chromosomes 1,5, and 15, respectively). miR-9 has been shown to be involved in the carcinogenesis and the metastatic process of cancers, either as an oncogene or as a tumour suppressor depending on cancer type [83,84].

Sromec et al. [85] proposed the high plasmatic miR-9 expression as a biomarker of NSCLC. In this study, plasma samples were collected from healthy donors and from NSCLC patients before surgery, and 1 month and 1 year after. Interestingly, following tumour resection, miR-9 levels significantly decreased below the normal level. Thus, the following of miR-9 plasma level could reflect the presence of NSCLC and the systemic response after tumour resection.

In NSCLC cell lines, several studies showed an up-regulation of miR-9 using miRNA microarray, RT-qPCR and bioinformatic analyses [86-92]. In primitive tumours of NSCLC, miR-9 expression was higher than that in adjacent normal tissue [93-95]. This up-regulation in primitive tumour was correlated to advanced tumour-node-metastasis (TNM 2009), tumour size, and lymph node metastasis [94]. Furthermore, a high level of miR-9 expression was significantly associated with poorer progression free survival and overall survival.

Expression level of miR-9 has also been described to influence oncologic drug efficiency. Low miR-9 expression in SCLC cell lines led to an increased sensitivity to etoposide and topotecan [96]. In adenocarcinoma cell lines, ectopic overexpression of miR-9 decreased the growth inhibitory effect of erlotinib [93]. Moreover, in adenocarcinoma cell lines, erlotinib downregulated miR-9 expression in a dose-dependent manner. The suggested mechanism was an activation of DNA methylation due to Erlotinib, leading to miR-9-1 transcription inhibition. DNA methylation is an epigenetic mechanism, occurring on CpG islands, responsible for transcriptional silencing. In resected NSCLC samples, methylation of miR-9 genes is frequently observed [97]. However, contradictory results were 
described concerning the prognostic role of miR-9 genes methylation associated to miR-9 inhibition in NSCLC $[89,93,97,98]$. Methylation of miR-9-3 was associated with a shorter overall survival, in lung squamous cell carcinoma [89], whereas methylated miR-9 genes were proposed as favourable prognosis biomarkers in NSCLC [97].

Moreover, several studies showed that miR-9 directly mediated E-Cadherin down-regulation in breast [99,100], prostate [101], oesophageal [102], ovarian [103], hepatocellular [104], and lung [95] carcinoma. miR-9 targets $C D H 1$, the E-Cadherin mRNA and downregulates E-Cadherin expression, leading to $\beta$-catenin signalling activation and cell motility and invasiveness increase [100]. E-Cadherin is a transmembrane calcium-dependent glycoprotein, which plays an important role in maintaining the polarity and the contact of epithelial cells. In cancer research, downregulation of E-cadherin has been shown to promote the metastatic process by allowing the dissociation of carcinomatous cells. A negative correlation between the loss of E-cadherin expression in cancer cells and the severity of the underlying disease has also been described [105-107]. These consequences of E-cadherin inactivation have been shown in different models, both in vivo and in vitro [108-112]. Loss of E-Cadherin expression in tumour tissues predicted poor overall survival in NSCLC patients $[113,114]$ and was associated with lymph node metastasis [113]. Moreover, in E-cadherin-deficient mouse model with lung adenocarcinoma, accelerated cancer progression and decreased survival were observed, associated with more metastatic sites number and in vitro, elevated migration of adenocarcinoma cells derived from this model [115].

Interestingly, miR-9 is also known to down-regulate the expression of Metastasis-Associated Lung Adenocarcinoma Transcript 1 (MALAT-1) [116]. miR-9 inhibits MALAT-1 expression through its direct binding on two miRNA binding sites in the MALAT-1 sequence, leading to MALAT-1 degradation in the nucleus [116]. MALAT-1 is a $7 \mathrm{~kb}$ long non-coding nuclear RNA, which is over-expressed in lung adenocarcinoma and other NSCLC cells [117-120]. MALAT-1 has been associated with metastasis in NSCLC and is known as a poor prognostic marker for survival in lung adenocarcinoma [116]. Indeed, MALAT-1 targets genes associated with lung cancer metastasis, involved in cell migration, tumor growth $[117,118]$ and it was suggested that MALAT-1 promotes lung cancer brain metastasis by epithelial to mesenchymal transition (EMT) induction [120]. In addition, all these studies concerning miR-9 and MALAT-1 expressions were performed on various cancer cell lines or primary tumors obtained from patients with stage I-III NSCLC, including adenocarcinoma, squamous cell carcinoma, or other large cell carcinoma. No study was performed on metastatic cells from patients with stage IV lung adenocarcinoma. Moreover, MALAT-1 can be a blood based biomarker for NSCLC as it is detectable and increased in peripheral human blood sample from patients compared to cancer-free controls [121].

\section{4. miR-9 and A-Type Lamins}

Two publications showed that miR-9 is physiologically and highly expressed in neural cells, in which it inhibits the expression of lamin A but not of lamin C, by directly targeting prelamin A mRNA [122,123]. In HGPS, this mechanism prevents progerin (abnormal farnesylated prelamin A) expression in neural tissue, which explains the normal cognitive development of patients affected by HGPS. Inversely, most organs and systems, in which miR-9 is slightly or not expressed, are affected by progerin accumulation.

Moreover, as described above, miR-9 is known to regulate the expression MALAT-1 [116], which is also implicated in the regulation of several splicing factors, such as serine-arginine (SR)-rich splicing factors (SRSF) 1, 2 and 3 [124]. SRSF1, like SRSF6, controls LMNA pre-mRNA alternative splicing, leading to the production of lamin A and progerin in HGPS cells and during physiological aging in a less extend $[21,125]$. MALAT-1 interacts with SRSF1 and modulates its expression in in vitro models by controlling the ratio of phosphorylated to dephosphorylated pools of SRSF1 [124,126]. SRSF1 and SRSF6 have been proposed as proto-oncogenes as they are overexpressed in many cancers $[127,128]$. Particularly in lung adenocarcinoma, high expression of SRSF1 is associated with the presence 
of metastases, a more aggressive phenotype, and chemotherapy resistance [77]. In human lung adenocarcinoma cell lines, SRSF1 overexpression lead to EMT, with the loss of epithelial markers (e.g., E-Cadherin) along with the acquisition of mesenchymal markers (e.g., vimentin, fibronectin, and N-cadherin) [77].

In view of all these data, the oncomiR miR-9 seems to be a central actor in the carcinogenesis and the metastatic process of NSCLC. Indeed, through its direct regulation on E-cadherin, MALAT-1 and Lamin A, it could act at different levels to increase the metastatic potential (Figure 1). miR-9 is thus proposed as a biomarker associated to a poor prognosis in NSCLC patients, correlated to adverse clinical features and unfavourable survival.

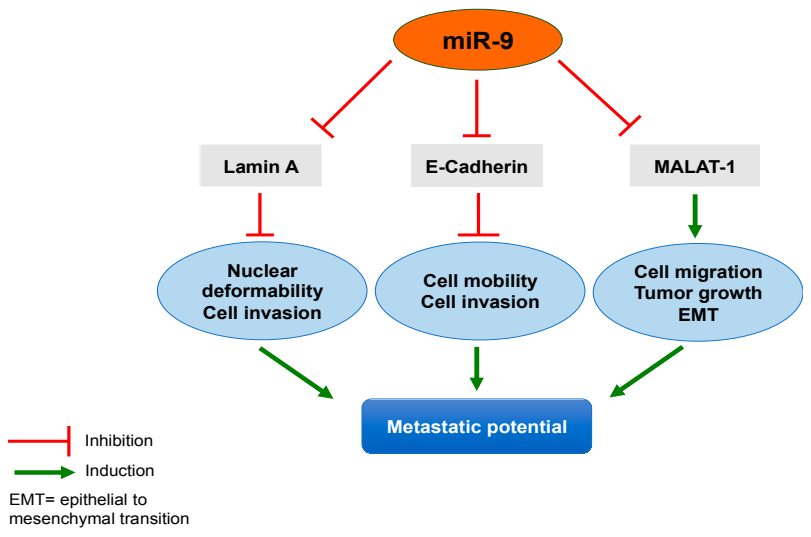

Figure 1. miR-9 as a potential central actor in the metastatic process of NSCLC. miR-9 was described to inhibit lamin A, E-cadherin, and MALAT-1 expression. Thus, miR-9 could indirectly regulate nuclear deformability, cell mobility, migration and invasion, tumor growth, and EMT, leading to the metastatic process in NSCLC.

\section{Conclusions and Future Perspectives}

Previous works showed that A-type lamins' levels were dramatically decreased in SCLC compared to NSCLC. In adenocarcinoma cells, A-type lamins' aberrant cytoplasmic localization or reduced expression, with a more important decrease of lamin A expression compared to lamin C, were described. Furthermore, most published data result from old studies, only descriptive, which did not establish a link with the prognosis of the disease. A recent work of our team showed a reduction of lamin A expression, but not of lamin C, in lung adenocarcinoma metastatic cells obtained from pleural effusions. This isolated reduction of lamin A was associated with a higher number of metastatic sites and a poor performance status [50]. Interestingly, this expression profile of A-type lamins was also correlated with metastatic potential and a poor prognosis in other cancer types, such as ovarian cancer [38] and prostate carcinoma [40]. Thus, the loss of A-type lamins' expression combined with the enhanced deformability of these cancer cells could confer them a high metastatic potential.

MiR-9 could be a good candidate to explain the reduction of lamin A expression in lung adenocarcinoma cells. We hypothesize that an up-regulation of miR-9 in cancer cells would inhibit lamin A expression without affecting lamin C expression, resulting to an increase of the nuclear deformability. Concomitantly, miR-9 would decrease the expression of the E-Cadherin, leading to EMT and allowing the dissociation of carcinomatous cells, increasing the metastatic potential. This hypothesis places miR- 9 in the centre of the potential metastatic regulation by increasing nuclear deformability, cell invasion, and mobility and migration linked to EMT, through the direct targeting lamin A and E-Cadherin mRNAs, as well as the MALAT-1 lncRNA. Moreover, as EMT has also been associated with chemotherapy resistance [129-131], the reduction of lamin A expression, through miR-9 regulation, could represent a predictive factor of therapy efficacy.

Thus, future works on metastatic cells as well as on primitive tumour tissues from lung adenocarcinoma would facilitate investigation of the link between miR-9, lamin A, E-cadherin, 
and MALAT-1 expression. This would further our understanding of the mechanisms explaining metastatic potential and help with the proposal of new prognostic tools for patients with metastatic lung adenocarcinoma, and perhaps pave the way for the identification of new therapeutic targets in this devastating disease.

Author Contributions: J.G., D.F., P.R. and E.K. analysed data and wrote the paper; S.P., V.D., N.L., F.B. and P.A. wrote the paper.

Funding: This work was supported by an ARARD (Association Régionale d'Aide Respiratoire à Domicile) grant, Parc d'activités de Napollon, 100 avenue des Templiers, 13676 Aubagne Cedex, France. Tel.: +33-442-848-701, Fax: +33-442-846-999, http:/ / www.arard.asso.fr/vous-etes-patient.html.

Acknowledgments: We thank Pierre Cau, Andrée Robaglia-Schlupp and Kévin Ostacolo for their help and continuous support.

Conflicts of Interest: E. Kaspi reports grants from ARARD (Association Régionale d'Aide Respiratoire à Domicile) grant, Parc d'activités de Napollon, 100 avenue des Templiers, 13676 Aubagne Cedex, France. Tel.: +33-442-848-701, Fax: +33-442-846-999. http://www.arard.asso.fr/vous-etes-patient.html., during the conduct of the study. Other authors declare no conflict of interest, which could influence the representation or interpretation of reported research results. The founding sponsors had no role in the design of the study; in the collection, analyses, or interpretation of data; in the writing of the manuscript, and in the decision to publish the results.

\section{References}

1. Lozano, R.; Naghavi, M.; Foreman, K.; Lim, S.; Shibuya, K.; Aboyans, V.; Abraham, J.; Adair, T.; Aggarwal, R.; Ahn, S.Y.; et al. Global and regional mortality from 235 causes of death for 20 age groups in 1990 and 2010: A systematic analysis for the Global Burden of Disease Study 2010. Lancet 2012, 380, 2095-2128. [CrossRef]

2. Siegel, R.L.; Miller, K.D.; Jemal, A. Cancer statistics, 2017. CA Cancer J. Clin. 2017, 67, 7-30. [CrossRef] [PubMed]

3. Novello, S.; Barlesi, F.; Califano, R.; Cufer, T.; Ekman, S.; Levra, M.G.; Kerr, K.; Popat, S.; Reck, M.; Senan, S.; et al. Metastatic non-small-cell lung cancer: ESMO Clinical Practice Guidelines for diagnosis, treatment and follow-up. Ann. Oncol. 2016, 27, v1-v27. [CrossRef] [PubMed]

4. Shea, M.; Costa, D.B.; Rangachari, D. Management of advanced non-small cell lung cancers with known mutations or rearrangements: Latest evidence and treatment approaches. Ther. Adv. Respir. Dis. 2016, 10, 113-129. [CrossRef] [PubMed]

5. Barlesi, F.; Mazieres, J.; Merlio, J.-P.; Debieuvre, D.; Mosser, J.; Lena, H.; Ouafik, L.; Besse, B.; Rouquette, I.; Westeel, V.; et al. Routine molecular profiling of patients with advanced non-small-cell lung cancer: Results of a 1-year nationwide programme of the French Cooperative Thoracic Intergroup (IFCT). Lancet 2016, 387, 1415-1426. [CrossRef]

6. Capo-Chichi, C.D.; Cai, K.Q.; Smedberg, J.; Ganjei-Azar, P.; Godwin, A.K.; Xu, X.-X. Loss of A-type lamin expression compromises nuclear envelope integrity in breast cancer. Chin. J. Cancer 2011, 30, 415-425. [CrossRef] [PubMed]

7. Zink, D.; Fische, A.H.; Nickerson, J.A. Nuclear structure in cancer cells. Nat. Rev. Cancer 2004, 4, 677-687. [CrossRef] [PubMed]

8. Butin-Israeli, V.; Adam, S.A.; Goldman, A.E.; Goldman, R.D. Nuclear lamin functions and disease. Trends Genet. 2012, 28, 464-471. [CrossRef] [PubMed]

9. Lammerding, J.; Schulze, P.C.; Takahashi, T.; Kozlov, S.; Sullivan, T.; Kamm, R.D.; Stewart, C.L.; Lee, R.T. Lamin A/C deficiency causes defective nuclear mechanics and mechanotransduction. J. Clin. Investig. 2004, 113, 370-378. [CrossRef] [PubMed]

10. Lammerding, J.; Fong, L.G.; Ji, J.Y.; Reue, K.; Stewart, C.L.; Young, S.G.; Lee, R.T. Lamins A and C but Not Lamin B1 Regulate Nuclear Mechanics. J. Biol. Chem. 2006, 281, 25768-25780. [CrossRef] [PubMed]

11. Redwood, A.B.; Perkins, S.M.; Vanderwaal, R.P.; Feng, Z.; Biehl, K.J.; Gonzalez-Suarez, I.; Morgado-Palacin, L.; Shi, W.; Sage, J.; Roti-Roti, J.L.; et al. A dual role for A-type lamins in DNA double-strand break repair. Cell Cycle 2011, 10, 2549-2560. [CrossRef] [PubMed]

12. Butin-Israeli, V.; Adam, S.A.; Goldman, R.D. Regulation of Nucleotide Excision Repair by Nuclear Lamin B1. PLoS ONE 2013, 8, e69169. [CrossRef] [PubMed] 
13. Mahen, R.; Hattori, H.; Lee, M.; Sharma, P.; Jeyasekharan, A.D.; Venkitaraman, A.R. A-Type Lamins Maintain the Positional Stability of DNA Damage Repair Foci in Mammalian Nuclei. PLoS ONE 2013, 8, e61893. [CrossRef] [PubMed]

14. Broers, J.L.V.; Ramaekers, F.C.S. The Role of the Nuclear Lamina in Cancer and Apoptosis. In Cancer Biology and the Nuclear Envelope; Schirmer, E.C., de las Heras, J.I., Eds.; Springer: New York, NY, USA, 2014; Volume 773, pp. 27-48. ISBN 9781489980311.

15. Ungricht, R.; Kutay, U. Mechanisms and functions of nuclear envelope remodelling. Nat. Rev. Mol. Cell Biol. 2017, 18, 229-245. [CrossRef] [PubMed]

16. Machiels, B.M.; Zorenc, A.H.; Endert, J.M.; Kuijpers, H.J.; van Eys, G.J.; Ramaekers, F.C.; Broers, J.L. An alternative splicing product of the lamin A/C gene lacks exon 10. J. Biol. Chem. 1996, 271, 9249-9253. [CrossRef] [PubMed]

17. Lin, F.; Worman, H.J. Structural organization of the human gene encoding nuclear lamin A and nuclear lamin C. J. Biol. Chem. 1993, 268, 16321-16326. [PubMed]

18. Dechat, T.; Pfleghaar, K.; Sengupta, K.; Shimi, T.; Shumaker, D.K.; Solimando, L.; Goldman, R.D. Nuclear lamins: Major factors in the structural organization and function of the nucleus and chromatin. Genes Dev. 2008, 22, 832-853. [CrossRef] [PubMed]

19. Frangioni, J.V.; Neel, B.G. Use of a general purpose mammalian expression vector for studying intracellular protein targeting: Identification of critical residues in the nuclear lamin A/C nuclear localization signal. J. Cell Sci. 1993, 105 Pt 2, 481-488. [PubMed]

20. Stuurman, N.; Heins, S.; Aebi, U. Nuclear Lamins: Their Structure, Assembly, and Interactions. J. Struct. Biol. 1998, 122, 42-66. [CrossRef] [PubMed]

21. Cau, P.; Navarro, C.; Harhouri, K.; Roll, P.; Sigaudy, S.; Kaspi, E.; Perrin, S.; De Sandre-Giovannoli, A.; Lévy, N. WITHDRAWN: Nuclear matrix, nuclear envelope and premature aging syndromes in a translational research perspective. Semin. Cell Dev. Biol. 2014. [CrossRef] [PubMed]

22. Prokocimer, M.; Davidovich, M.; Nissim-Rafinia, M.; Wiesel-Motiuk, N.; Bar, D.Z.; Barkan, R.; Meshorer, E.; Gruenbaum, Y. Nuclear lamins: Key regulators of nuclear structure and activities. J. Cell. Mol. Med. 2009, 13, 1059-1085. [CrossRef] [PubMed]

23. Broers, J.L.V.; Ramaekers, F.C.S.; Bonne, G.; Yaou, R.B.; Hutchison, C.J. Nuclear Lamins: Laminopathies and Their Role in Premature Ageing. Physiol. Rev. 2006, 86, 967-1008. [CrossRef] [PubMed]

24. Gerace, L.; Burke, B. Functional Organization of the Nuclear Envelope. Annu. Rev. Cell Biol. 1988, 4, 335-374. [CrossRef] [PubMed]

25. Krohne, G.; Benavente, R. The nuclear lamins. A multigene family of proteins in evolution and differentiation. Exp. Cell Res. 1986, 162, 1-10. [CrossRef]

26. Nigg, E.A. Assembly and cell cycle dynamics of the nuclear lamina. Semin. Cell Biol. 1992, 3, $245-253$. [CrossRef]

27. Broers, J.L.; Machiels, B.M.; Kuijpers, H.J.; Smedts, F.; van den Kieboom, R.; Raymond, Y.; Ramaekers, F.C. A- and B-type lamins are differentially expressed in normal human tissues. Histochem. Cell Biol. 1997, 107, 505-517. [CrossRef] [PubMed]

28. Oguchi, M.; Sagara, J.; Matsumoto, K.; Saida, T.; Taniguchi, S. Expression of lamins depends on epidermal differentiation and transformation. Br. J. Dermatol. 2002, 147, 853-858. [CrossRef] [PubMed]

29. Irianto, J.; Pfeifer, C.R.; Ivanovska, I.L.; Swift, J.; Discher, D.E. Nuclear lamins in cancer. Cell. Mol. Bioeng. 2016, 9, 258-267. [CrossRef] [PubMed]

30. Swift, J.; Ivanovska, I.L.; Buxboim, A.; Harada, T.; Dingal, P.C.D.P.; Pinter, J.; Pajerowski, J.D.; Spinler, K.R.; Shin, J.-W.; Tewari, M.; et al. Nuclear Lamin-A Scales with Tissue Stiffness and Enhances Matrix-Directed Differentiation. Science 2013, 341, 1240104. [CrossRef] [PubMed]

31. Frankel, D.; Delecourt, V.; Harhouri, K.; De Sandre-Giovannoli, A.; Lévy, N.; Kaspi, E.; Roll, P. MicroRNAs in hereditary and sporadic premature aging syndromes and other laminopathies. Aging Cell 2018, e12766. [CrossRef] [PubMed]

32. De Sandre-Giovannoli, A. Lamin A Truncation in Hutchinson-Gilford Progeria. Science 2003, $300,2055$. [CrossRef] [PubMed]

33. Eriksson, M.; Brown, W.T.; Gordon, L.B.; Glynn, M.W.; Singer, J.; Scott, L.; Erdos, M.R.; Robbins, C.M.; Moses, T.Y.; Berglund, P.; et al. Recurrent de novo point mutations in lamin A cause Hutchinson-Gilford progeria syndrome. Nature 2003, 423, 293-298. [CrossRef] [PubMed] 
34. Kubben, N.; Misteli, T. Shared molecular and cellular mechanisms of premature ageing and ageing-associated diseases. Nat. Rev. Mol. Cell Biol. 2017, 18, 595-609. [CrossRef] [PubMed]

35. Fernandez, P.; Scaffidi, P.; Markert, E.; Lee, J.-H.; Rane, S.; Misteli, T. Transformation Resistance in a Premature Aging Disorder Identifies a Tumor-Protective Function of BRD4. Cell Rep. 2014, 9, 248-260. [CrossRef] [PubMed]

36. Sakthivel, K.M.; Sehgal, P. A novel role of lamins from genetic disease to cancer biomarkers. Oncol. Rev. 2016, 10. [CrossRef] [PubMed]

37. Belt, E.J.T.; Fijneman, R.J.A.; van den Berg, E.G.; Bril, H.; Delis-van Diemen, P.M.; Tijssen, M.; van Essen, H.F.; de Lange-de Klerk, E.S.M.; Beliën, J.A.M.; Stockmann, H.B.A.C.; et al. Loss of lamin A/C expression in stage II and III colon cancer is associated with disease recurrence. Eur. J. Cancer 2011, 47, 1837-1845. [CrossRef] [PubMed]

38. Gong, G.; Chen, P.; Li, L.; Tan, H.; Zhou, J.; Zhou, Y.; Yang, X.; Wu, X. Loss of lamin A but not lamin C expression in epithelial ovarian cancer cells is associated with metastasis and poor prognosis. Pathol. Res. Pract. 2015, 211, 175-182. [CrossRef] [PubMed]

39. Matsumoto, A.; Hieda, M.; Yokoyama, Y.; Nishioka, Y.; Yoshidome, K.; Tsujimoto, M.; Matsuura, N. Global loss of a nuclear lamina component, lamin A/C, and LINC complex components SUN1, SUN2, and nesprin-2 in breast cancer. Cancer Med. 2015, 4, 1547-1557. [CrossRef] [PubMed]

40. Saarinen, I.; Mirtti, T.; Seikkula, H.; Boström, P.J.; Taimen, P. Differential Predictive Roles of A- and B-Type Nuclear Lamins in Prostate Cancer Progression. PLoS ONE 2015, 10, e0140671. [CrossRef] [PubMed]

41. Wu, Z.; Wu, L.; Weng, D.; Xu, D.; Geng, J.; Zhao, F. Reduced expression of lamin A/C correlates with poor histological differentiation and prognosis in primary gastric carcinoma. J. Exp. Clin. Cancer Res. 2009, 28, 8. [CrossRef] [PubMed]

42. Cicchillitti, L.; Corrado, G.; Carosi, M.; Dabrowska, M. E.; Loria, R.; Falcioni, R.; Cutillo, G.; Piaggio, G.; Vizza, E. Prognostic role of NF-YA splicing isoforms and Lamin A status in low grade endometrial cancer. Oncotarget 2017, 8, 7935-7945. [CrossRef] [PubMed]

43. Kong, L.; Schäfer, G.; Bu, H.; Zhang, Y.; Zhang, Y.; Klocker, H. Lamin A/C protein is overexpressed in tissue-invading prostate cancer and promotes prostate cancer cell growth, migration and invasion through the PI3K/AKT/PTEN pathway. Carcinogenesis 2012, 33, 751-759. [CrossRef] [PubMed]

44. Willis, N.D.; Cox, T.R.; Rahman-Casañs, S.F.; Smits, K.; Przyborski, S.A.; van den Brandt, P.; van Engeland, M.; Weijenberg, M.; Wilson, R.G.; de Bruïne, A.; et al. Lamin A/C Is a Risk Biomarker in Colorectal Cancer. PLoS ONE 2008, 3, e2988. [CrossRef] [PubMed]

45. Wang, Y.; Wu, R.; Cho, K.R.; Thomas, D.G.; Gossner, G.; Liu, J.R.; Giordano, T.J.; Shedden, K.A.; Misek, D.E.; Lubman, D.M. Differential Protein Mapping of Ovarian Serous Adenocarcinomas: Identification of Potential Markers for Distinct Tumor Stage. J. Proteome Res. 2009, 8, 1452-1463. [CrossRef] [PubMed]

46. Kaufmann, S.H.; Mabry, M.; Jasti, R.; Shaper, J.H. Differential expression of nuclear envelope lamins A and C in human lung cancer cell lines. Cancer Res. 1991, 51, 581-586. [PubMed]

47. Broers, J.L.; Raymond, Y.; Rot, M.K.; Kuijpers, H.; Wagenaar, S.S.; Ramaekers, F.C. Nuclear A-type lamins are differentially expressed in human lung cancer subtypes. Am. J. Pathol. 1993, 143, 211-220. [PubMed]

48. Moss, S.F.; Krivosheyev, V.; de Souza, A.; Chin, K.; Gaetz, H.P.; Chaudhary, N.; Worman, H.J.; Holt, P.R. Decreased and aberrant nuclear lamin expression in gastrointestinal tract neoplasms. Gut 1999, 45, 723-729. [CrossRef] [PubMed]

49. Machiels, B.M.; Broers, J.L.; Raymond, Y.; de Ley, L.; Kuijpers, H.J.; Caberg, N.E.; Ramaekers, F.C. Abnormal A-type lamin organization in a human lung carcinoma cell line. Eur. J. Cell Biol. 1995, 67, 328-335. [PubMed]

50. Kaspi, E.; Frankel, D.; Guinde, J.; Perrin, S.; Laroumagne, S.; Robaglia-Schlupp, A.; Ostacolo, K.; Harhouri, K.; Tazi-Mezalek, R.; Micallef, J.; et al. Low lamin A expression in lung adenocarcinoma cells from pleural effusions is a pejorative factor associated with high number of metastatic sites and poor Performance status. PLoS ONE 2017, 12, e0183136. [CrossRef] [PubMed]

51. Liao, G.; Wang, M.; Ou, Y.; Zhao, Y. IGF-1-induced epithelial-mesenchymal transition in MCF-7 cells is mediated by MUC1. Cell. Signal. 2014, 26, 2131-2137. [CrossRef] [PubMed]

52. Nath, S.; Mukherjee, P. MUC1: A multifaceted oncoprotein with a key role in cancer progression. Trends Mol. Med. 2014, 20, 332-342. [CrossRef] [PubMed]

53. Hutchison, C.J.; Worman, H.J. A-type lamins: Guardians of the soma? Nat. Cell Biol. 2004, 6, $1062-1067$. [CrossRef] [PubMed] 
54. Guilak, F.; Tedrow, J.R.; Burgkart, R. Viscoelastic Properties of the Cell Nucleus. Biochem. Biophys. Res. Commun. 2000, 269, 781-786. [CrossRef] [PubMed]

55. Davidson, P.M.; Sliz, J.; Isermann, P.; Denais, C.; Lammerding, J. Design of a microfluidic device to quantify dynamic intra-nuclear deformation during cell migration through confining environments. Integr. Biol. 2015, 7, 1534-1546. [CrossRef] [PubMed]

56. Yabuki, M.; Miyake, T.; Doi, Y.; Fujiwara, T.; Hamazaki, K.; Yoshioka, T.; Horton, A.A.; Utsumi, K. Role of nuclear lamins in nuclear segmentation of human neutrophils. Physiol. Chem. Phys. Med. NMR 1999, 31, 77-84. [PubMed]

57. Pajerowski, J.D.; Dahl, K.N.; Zhong, F.L.; Sammak, P.J.; Discher, D.E. Physical plasticity of the nucleus in stem cell differentiation. Proc. Natl. Acad. Sci. USA 2007, 104, 15619-15624. [CrossRef] [PubMed]

58. Tsai, J.-W.; Chen, Y.; Kriegstein, A.R.; Vallee, R.B. LIS1 RNA interference blocks neural stem cell division, morphogenesis, and motility at multiple stages. J. Cell Biol. 2005, 170, 935-945. [CrossRef] [PubMed]

59. Denais, C.; Lammerding, J. Nuclear Mechanics in Cancer. In Cancer Biology and the Nuclear Envelope; Schirmer, E.C., de las Heras, J.I., Eds.; Springer: New York, NY, USA, 2014; Volume 773, pp. 435-470. ISBN 9781489980311.

60. Lu, Q.-Y.; Yang, Y.; Jin, Y.S.; Zhang, Z.-F.; Heber, D.; Li, F.P.; Dubinett, S.M.; Sondej, M.A.; Loo, J.A.; Rao, J.Y. Effects of green tea extract on lung cancer A549 cells: Proteomic identification of proteins associated with cell migration. Proteomics 2009, 9, 757-767. [CrossRef] [PubMed]

61. Lee, R.C.; Feinbaum, R.L.; Ambros, V. The C. elegans heterochronic gene lin-4 encodes small RNAs with antisense complementarity to lin-14. Cell 1993, 75, 843-854. [CrossRef]

62. Lee, Y.; Ahn, C.; Han, J.; Choi, H.; Kim, J.; Yim, J.; Lee, J.; Provost, P.; Rådmark, O.; Kim, S.; Kim, V.N. The nuclear RNase III Drosha initiates microRNA processing. Nature 2003, 425, 415-419. [CrossRef] [PubMed]

63. Hutvagner, G. A Cellular Function for the RNA-Interference Enzyme Dicer in the Maturation of the let-7 Small Temporal RNA. Science 2001, 293, 834-838. [CrossRef] [PubMed]

64. Jonas, S.; Izaurralde, E. Towards a molecular understanding of microRNA-mediated gene silencing. Nat. Rev. Genet. 2015, 16, 421-433. [CrossRef] [PubMed]

65. Lim, L.P.; Lau, N.C.; Garrett-Engele, P.; Grimson, A.; Schelter, J.M.; Castle, J.; Bartel, D.P.; Linsley, P.S.; Johnson, J.M. Microarray analysis shows that some microRNAs downregulate large numbers of target mRNAs. Nature 2005, 433, 769-773. [CrossRef] [PubMed]

66. Krek, A.; Grün, D.; Poy, M.N.; Wolf, R.; Rosenberg, L.; Epstein, E.J.; MacMenamin, P.; da Piedade, I.; Gunsalus, K.C.; Stoffel, M.; et al. Combinatorial microRNA target predictions. Nat. Genet. 2005, 37, 495-500. [CrossRef] [PubMed]

67. Place, R.F.; Li, L.-C.; Pookot, D.; Noonan, E.J.; Dahiya, R. MicroRNA-373 induces expression of genes with complementary promoter sequences. Proc. Natl. Acad. Sci. USA 2008, 105, 1608-1613. [CrossRef] [PubMed]

68. Esquela-Kerscher, A.; Slack, F.J. Oncomirs-MicroRNAs with a role in cancer. Nat. Rev. Cancer 2006, 6, 259-269. [CrossRef] [PubMed]

69. Beg, M.S.; Brenner, A.J.; Sachdev, J.; Borad, M.; Kang, Y.-K.; Stoudemire, J.; Smith, S.; Bader, A.G.; Kim, S.; Hong, D.S. Phase I study of MRX34, a liposomal miR-34a mimic, administered twice weekly in patients with advanced solid tumors. Investig. New Drugs 2017, 35, 180-188. [CrossRef] [PubMed]

70. Slaby, O.; Laga, R.; Sedlacek, O. Therapeutic targeting of non-coding RNAs in cancer. Biochem. J. 2017, 474, 4219-4251. [CrossRef] [PubMed]

71. Wilk, G.; Braun, R. Integrative analysis reveals disrupted pathways regulated by microRNAs in cancer. Nucleic Acids Res. 2018, 46, 1089-1101. [CrossRef] [PubMed]

72. Tian, Z.; Wen, S.; Zhang, Y.; Shi, X.; Zhu, Y.; Xu, Y.; Lv, H.; Wang, G. Identification of dysregulated long non-coding RNAs/microRNAs/mRNAs in TNM I stage lung adenocarcinoma. Oncotarget 2017, 8. [CrossRef] [PubMed]

73. Hsu, Y.-L.; Hung, J.-Y.; Lee, Y.-L.; Chen, F.-W.; Chang, K.-F.; Chang, W.-A.; Tsai, Y.-M.; Chong, I.-W.; Kuo, P.-L. Identification of novel gene expression signature in lung adenocarcinoma by using next-generation sequencing data and bioinformatics analysis. Oncotarget 2017, 8, 104831. [CrossRef] [PubMed]

74. Uddin, A.; Chakraborty, S. Role of miRNAs in lung cancer. J. Cell. Physiol. 2018. [CrossRef] [PubMed] 
75. Okamoto, S.; Okamoto, A.; Nikaido, T.; Saito, M.; Takao, M.; Yanaihara, N.; Takakura, S.; Ochiai, K.; Tanaka, T. Mesenchymal to epithelial transition in the human ovarian surface epithelium focusing on inclusion cysts. Oncol. Rep. 2009, 21, 1209-1214. [CrossRef] [PubMed]

76. Zhai, X.; Zhu, H.; Wang, W.; Zhang, S.; Zhang, Y.; Mao, G. Abnormal expression of EMT-related proteins, S100A4, vimentin and E-cadherin, is correlated with clinicopathological features and prognosis in HCC. Med. Oncol. 2014, 31, 970. [CrossRef] [PubMed]

77. Gout, S.; Brambilla, E.; Boudria, A.; Drissi, R.; Lantuejoul, S.; Gazzeri, S.; Eymin, B. Abnormal Expression of the Pre-mRNA Splicing Regulators SRSF1, SRSF2, SRPK1 and SRPK2 in Non Small Cell Lung Carcinoma. PLoS ONE 2012, 7, e46539. [CrossRef] [PubMed]

78. Mongroo, P.S.; Rustgi, A.K. The role of the miR-200 family in epithelial-mesenchymal transition. Cancer Biol. Ther. 2010, 10, 219-222. [CrossRef] [PubMed]

79. Lang, Y.; Xu, S.; Ma, J.; Wu, J.; Jin, S.; Cao, S.; Yu, Y. MicroRNA-429 induces tumorigenesis of human non-small cell lung cancer cells and targets multiple tumor suppressor genes. Biochem. Biophys. Res. Commun. 2014, 450, 154-159. [CrossRef] [PubMed]

80. Yang, Y.; Chen, K.; Zhou, Y.; Hu, Z.; Chen, S.; Huang, Y. Application of serum microRNA-9-5p, 21-5p, and 223-3p combined with tumor markers in the diagnosis of non-small-cell lung cancer in Yunnan in southwestern China. OncoTargets Ther. 2018, 11, 587-597. [CrossRef] [PubMed]

81. Nadal, E.; Truini, A.; Nakata, A.; Lin, J.; Reddy, R.M.; Chang, A.C.; Ramnath, N.; Gotoh, N.; Beer, D.G.; Chen, G. A Novel Serum 4-microRNA Signature for Lung Cancer Detection. Sci. Rep. 2015, 5, 12464. [CrossRef] [PubMed]

82. Zhu, W.; He, J.; Chen, D.; Zhang, B.; Xu, L.; Ma, H.; Liu, X.; Zhang, Y.; Le, H. Expression of miR-29c, miR-93, and miR-429 as Potential Biomarkers for Detection of Early Stage Non-Small Lung Cancer. PLoS ONE 2014, 9, e87780. [CrossRef] [PubMed]

83. Lujambio, A.; Calin, G.A.; Villanueva, A.; Ropero, S.; Sanchez-Cespedes, M.; Blanco, D.; Montuenga, L.M.; Rossi, S.; Nicoloso, M.S.; Faller, W.J.; et al. A microRNA DNA methylation signature for human cancer metastasis. Proc. Natl. Acad. Sci. USA 2008, 105, 13556-13561. [CrossRef] [PubMed]

84. Senyuk, V.; Zhang, Y.; Liu, Y.; Ming, M.; Premanand, K.; Zhou, L.; Chen, P.; Chen, J.; Rowley, J.D.; Nucifora, G.; et al. Critical role of miR-9 in myelopoiesis and EVI1-induced leukemogenesis. Proc. Natl. Acad. Sci. USA 2013, 110, 5594-5599. [CrossRef] [PubMed]

85. Sromek, M.; Glogowski, M.; Chechlinska, M.; Kulinczak, M.; Szafron, L.; Zakrzewska, K.; Owczarek, J.; Wisniewski, P.; Wlodarczyk, R.; Talarek, L.; et al. Changes in plasma miR-9, miR-16, miR-205 and miR-486 levels after non-small cell lung cancer resection. Cell. Oncol. 2017, 40, 529-536. [CrossRef] [PubMed]

86. Volinia, S.; Calin, G.A.; Liu, C.-G.; Ambs, S.; Cimmino, A.; Petrocca, F.; Visone, R.; Iorio, M.; Roldo, C.; Ferracin, M.; et al. A microRNA expression signature of human solid tumors defines cancer gene targets. Proc. Natl. Acad. Sci. USA 2006, 103, 2257-2261. [CrossRef] [PubMed]

87. Crawford, M.; Batte, K.; Yu, L.; Wu, X.; Nuovo, G.J.; Marsh, C.B.; Otterson, G.A.; Nana-Sinkam, S.P. MicroRNA 133B targets pro-survival molecules MCL-1 and BCL2L2 in lung cancer. Biochem. Biophys. Res. Commun. 2009, 388, 483-489. [CrossRef] [PubMed]

88. Võsa, U.; Vooder, T.; Kolde, R.; Fischer, K.; Välk, K.; Tõnisson, N.; Roosipuu, R.; Vilo, J.; Metspalu, A.; Annilo, T. Identification of miR-374a as a prognostic marker for survival in patients with early-stage nonsmall cell lung cancer. Genes Chromosom. Cancer 2011, 50, 812-822. [CrossRef] [PubMed]

89. Heller, G.; Weinzierl, M.; Noll, C.; Babinsky, V.; Ziegler, B.; Altenberger, C.; Minichsdorfer, C.; Lang, G.; Dome, B.; End-Pfutzenreuter, A.; et al. Genome-Wide miRNA Expression Profiling Identifies miR-9-3 and miR-193a as Targets for DNA Methylation in Non-Small Cell Lung Cancers. Clin. Cancer Res. 2012, 18, 1619-1629. [CrossRef] [PubMed]

90. Wang, R.; Chen, X.-F.; Shu, Y.-Q. Prediction of non-small cell lung cancer metastasis-associated microRNAs using bioinformatics. Am. J. Cancer Res. 2015, 5, 32-51. [PubMed]

91. Kang, H.-W.; Crawford, M.; Fabbri, M.; Nuovo, G.; Garofalo, M.; Nana-Sinkam, S.P.; Friedman, A. A Mathematical Model for MicroRNA in Lung Cancer. PLoS ONE 2013, 8, e53663. [CrossRef] [PubMed]

92. Hu, L.; Ai, J.; Long, H.; Liu, W.; Wang, X.; Zuo, Y.; Li, Y.; Wu, Q.; Deng, Y. Integrative microRNA and gene profiling data analysis reveals novel biomarkers and mechanisms for lung cancer. Oncotarget 2016, 7, 8441. [CrossRef] [PubMed] 
93. Chen, X.; Zhu, L.; Ma, Z.; Sun, G.; Luo, X.; Li, M.; Zhai, S.; Li, P.; Wang, X. Oncogenic miR-9 is a target of erlotinib in NSCLCs. Sci. Rep. 2015, 5. [CrossRef] [PubMed]

94. Xu, T.; Liu, X.; Han, L.; Shen, H.; Liu, L.; Shu, Y. Up-regulation of miR-9 expression as a poor prognostic biomarker in patients with non-small cell lung cancer. Clin. Transl. Oncol. 2014, 16, 469-475. [CrossRef] [PubMed]

95. Wang, H.; Wu, Q.; Zhang, Y.; Zhang, H.-N.; Wang, Y.-B.; Wang, W. TGF- $\beta 1$-induced epithelial-mesenchymal transition in lung cancer cells involves upregulation of miR-9 and downregulation of its target, E-cadherin. Cell. Mol. Biol. Lett. 2017, 22, 22. [CrossRef] [PubMed]

96. Polley, E.; Kunkel, M.; Evans, D.; Silvers, T.; Delosh, R.; Laudeman, J.; Ogle, C.; Reinhart, R.; Selby, M.; Connelly, J.; et al. Small Cell Lung Cancer Screen of Oncology Drugs, Investigational Agents, and Gene and microRNA Expression. J. Natl. Cancer Inst. 2016, 108, djw122. [CrossRef] [PubMed]

97. Muraoka, T.; Soh, J.; Toyooka, S.; Maki, Y.; Shien, K.; Furukawa, M.; Ueno, T.; Tanaka, N.; Yamamoto, H.; Asano, H.; et al. Impact of aberrant methylation of microRNA-9 family members on non-small cell lung cancers. Mol. Clin. Oncol. 2013, 1, 185-189. [CrossRef] [PubMed]

98. Wang, J.; Yang, B.; Han, L.; Li, X.; Tao, H.; Zhang, S.; Hu, Y. Demethylation of miR-9-3 and miR-193a Genes Suppresses Proliferation and Promotes Apoptosis in Non-Small Cell Lung Cancer Cell Lines. Cell. Physiol. Biochem. 2013, 32, 1707-1719. [CrossRef] [PubMed]

99. Gwak, J.M.; Kim, H.J.; Kim, E.J.; Chung, Y.R.; Yun, S.; Seo, A.N.; Lee, H.J.; Park, S.Y. MicroRNA-9 is associated with epithelial-mesenchymal transition, breast cancer stem cell phenotype, and tumor progression in breast cancer. Breast Cancer Res. Treat. 2014, 147, 39-49. [CrossRef] [PubMed]

100. Ma, L.; Young, J.; Prabhala, H.; Pan, E.; Mestdagh, P.; Muth, D.; Teruya-Feldstein, J.; Reinhardt, F.; Onder, T.T.; Valastyan, S.; et al. miR-9, a MYC/MYCN-activated microRNA, regulates E-cadherin and cancer metastasis. Nat. Cell Biol. 2010. [CrossRef] [PubMed]

101. Seashols-Williams, S.J.; Budd, W.; Clark, G.C.; Wu, Q.; Daniel, R.; Dragoescu, E.; Zehner, Z.E. miR-9 Acts as an OncomiR in Prostate Cancer through Multiple Pathways That Drive Tumour Progression and Metastasis. PLoS ONE 2016, 11, e0159601. [CrossRef] [PubMed]

102. Song, Y.; Li, J.; Zhu, Y.; Dai, Y.; Zeng, T.; Liu, L.; Li, J.; Wang, H.; Qin, Y.; Zeng, M.; et al. MicroRNA-9 promotes tumor metastasis via repressing E-cadherin in esophageal squamous cell carcinoma. Oncotarget 2014, 5, 11669. [CrossRef] [PubMed]

103. Yanaihara, N.; Noguchi, Y.; Saito, M.; Takenaka, M.; Takakura, S.; Yamada, K.; Okamoto, A. MicroRNA Gene Expression Signature Driven by miR-9 Overexpression in Ovarian Clear Cell Carcinoma. PLoS ONE 2016, 11, e0162584. [CrossRef] [PubMed]

104. Ding, G.; Peng, Z.; Shang, J.; Kang, Y.; Ning, H.; Mao, C. LincRNA-p21 inhibits invasion and metastasis of hepatocellular carcinoma through miR-9/E-cadherin cascade signaling pathway molecular mechanism. OncoTargets Ther. 2017, 10, 3241-3247. [CrossRef] [PubMed]

105. Yap, A.S. The morphogenetic role of cadherin cell adhesion molecules in human cancer: A thematic review. Cancer Investig. 1998, 16, 252-261. [CrossRef]

106. Cowin, P.; Rowlands, T.M.; Hatsell, S.J. Cadherins and catenins in breast cancer. Curr. Opin. Cell Biol. 2005, 17, 499-508. [CrossRef] [PubMed]

107. Junghans, D.; Haas, I.G.; Kemler, R. Mammalian cadherins and protocadherins: About cell death, synapses and processing. Curr. Opin. Cell Biol. 2005, 17, 446-452. [CrossRef] [PubMed]

108. Frixen, U.H.; Behrens, J.; Sachs, M.; Eberle, G.; Voss, B.; Warda, A.; Löchner, D.; Birchmeier, W. E-cadherin-mediated cell-cell adhesion prevents invasiveness of human carcinoma cells. J. Cell Biol. 1991, 113, 173-185. [CrossRef] [PubMed]

109. Vleminckx, K.; Vakaet, L.; Mareel, M.; Fiers, W.; van Roy, F. Genetic manipulation of E-cadherin expression by epithelial tumor cells reveals an invasion suppressor role. Cell 1991, 66, 107-119. [CrossRef]

110. Perl, A.-K.; Wilgenbus, P.; Dahl, U.; Semb, H.; Christofori, G. A causal role for E-cadherin in the transition from adenoma to carcinoma. Nature 1998, 392, 190-193. [CrossRef] [PubMed]

111. Derksen, P.W.B.; Liu, X.; Saridin, F.; van der Gulden, H.; Zevenhoven, J.; Evers, B.; van Beijnum, J.R.; Griffioen, A.W.; Vink, J.; Krimpenfort, P.; et al. Somatic inactivation of E-cadherin and p53 in mice leads to metastatic lobular mammary carcinoma through induction of anoikis resistance and angiogenesis. Cancer Cell 2006, 10, 437-449. [CrossRef] [PubMed] 
112. Onder, T.T.; Gupta, P.B.; Mani, S.A.; Yang, J.; Lander, E.S.; Weinberg, R.A. Loss of E-Cadherin Promotes Metastasis via Multiple Downstream Transcriptional Pathways. Cancer Res. 2008, 68, 3645-3654. [CrossRef] [PubMed]

113. Fan, C.; Miao, Y.; Zhang, X.; Liu, D.; Jiang, G.; Lin, X.; Han, Q.; Luan, L.; Xu, Z.; Wang, E. Btbd7 contributes to reduced E-cadherin expression and predicts poor prognosis in non-small cell lung cancer. BMC Cancer 2014, 14, 704. [CrossRef] [PubMed]

114. Wang, G.; Ma, W.; Li, Y.; Jiang, Y.; Ma, G.; Zhang, X.; Meng, L.; Du, J. Prognostic value of Twist, Snail and E-cadherin expression in pathological N0 non-small-cell lung cancer: A retrospective cohort study. Eur. J. Cardio-Thorac. Surg. 2018. [CrossRef] [PubMed]

115. Sinkevicius, K.W.; Bellaria, K.J.; Barrios, J.; Pessina, P.; Gupta, M.; Brainson, C.F.; Bronson, R.T.; Kim, C.F. E-cadherin Loss Accelerates Tumor Progression and Metastasis in a Mouse Model of Lung Adenocarcinoma. Am. J. Respir. Cell Mol. Biol. 2018. [CrossRef] [PubMed]

116. Leucci, E.; Patella, F.; Waage, J.; Holmstrøm, K.; Lindow, M.; Porse, B.; Kauppinen, S.; Lund, A.H. microRNA-9 targets the long non-coding RNA MALAT1 for degradation in the nucleus. Sci. Rep. 2013, 3, 2535. [CrossRef] [PubMed]

117. Gutschner, T.; Hammerle, M.; Eissmann, M.; Hsu, J.; Kim, Y.; Hung, G.; Revenko, A.; Arun, G.; Stentrup, M.; Gross, M.; et al. The Noncoding RNA MALAT1 Is a Critical Regulator of the Metastasis Phenotype of Lung Cancer Cells. Cancer Res. 2013, 73, 1180-1189. [CrossRef] [PubMed]

118. Gutschner, T.; Hämmerle, M.; Diederichs, S. MALAT1-A paradigm for long noncoding RNA function in cancer. J. Mol. Med. 2013, 91, 791-801. [CrossRef] [PubMed]

119. Schmidt, L.H.; Spieker, T.; Koschmieder, S.; Humberg, J.; Jungen, D.; Bulk, E.; Hascher, A.; Wittmer, D.; Marra, A.; Hillejan, L.; et al. The Long Noncoding MALAT-1 RNA Indicates a Poor Prognosis in Non-small Cell Lung Cancer and Induces Migration and Tumor Growth. J. Thorac. Oncol. 2011, 6, 1984-1992. [CrossRef] [PubMed]

120. Shen, L.; Chen, L.; Wang, Y.; Jiang, X.; Xia, H.; Zhuang, Z. Long noncoding RNA MALAT1 promotes brain metastasis by inducing epithelial-mesenchymal transition in lung cancer. J. Neuro-Oncol. 2015, 121, 101-108. [CrossRef] [PubMed]

121. Weber, D.; Johnen, G.; Casjens, S.; Bryk, O.; Pesch, B.; Jöckel, K.-H.; Kollmeier, J.; Brüning, T. Evaluation of long noncoding RNA MALAT1 as a candidate blood-based biomarker for the diagnosis of non-small cell lung cancer. BMC Res. Notes 2013, 6, 518. [CrossRef] [PubMed]

122. Jung, H.-J.; Coffinier, C.; Choe, Y.; Beigneux, A.P.; Davies, B.S.J.; Yang, S.H.; Barnes, R.H.; Hong, J.; Sun, T.; Pleasure, S.J.; et al. Regulation of prelamin A but not lamin C by miR-9, a brain-specific microRNA. Proc. Natl. Acad. Sci. USA 2012, 109, E423-E431. [CrossRef] [PubMed]

123. Nissan, X.; Blondel, S.; Navarro, C.; Maury, Y.; Denis, C.; Girard, M.; Martinat, C.; De Sandre-Giovannoli, A.; Levy, N.; Peschanski, M. Unique Preservation of Neural Cells in Hutchinson-Gilford Progeria Syndrome Is Due to the Expression of the Neural-Specific miR-9 MicroRNA. Cell Rep. 2012, 2, 1-9. [CrossRef] [PubMed]

124. Tripathi, V.; Ellis, J.D.; Shen, Z.; Song, D.Y.; Pan, Q.; Watt, A.T.; Freier, S.M.; Bennett, C.F.; Sharma, A.; Bubulya, P.A.; et al. The Nuclear-Retained Noncoding RNA MALAT1 Regulates Alternative Splicing by Modulating SR Splicing Factor Phosphorylation. Mol. Cell 2010, 39, 925-938. [CrossRef] [PubMed]

125. Scaffidi, P. Lamin A-Dependent Nuclear Defects in Human Aging. Science 2006, 312, 1059-1063. [CrossRef] [PubMed]

126. Lin, R.; Roychowdhury-Saha, M.; Black, C.; Watt, A.T.; Marcusson, E.G.; Freier, S.M.; Edgington, T.S. Control of RNA processing by a large non-coding RNA over-expressed in carcinomas. FEBS Lett. 2011, 585, 671-676. [CrossRef] [PubMed]

127. Das, S.; Krainer, A.R. Emerging Functions of SRSF1, Splicing Factor and Oncoprotein, in RNA Metabolism and Cancer. Mol. Cancer Res. 2014, 12, 1195-1204. [CrossRef] [PubMed]

128. Cohen-Eliav, M.; Golan-Gerstl, R.; Siegfried, Z.; Andersen, C.L.; Thorsen, K.; Ørntoft, T.F.; Mu, D.; Karni, R. The splicing factor SRSF6 is amplified and is an oncoprotein in lung and colon cancers: SRSF6 is amplified and is an oncoprotein in lung and colon cancers. J. Pathol. 2013, 229, 630-639. [CrossRef] [PubMed] 
129. Fischer, K.R.; Durrans, A.; Lee, S.; Sheng, J.; Li, F.; Wong, S.T.C.; Choi, H.; El Rayes, T.; Ryu, S.; Troeger, J.; et al. Epithelial-to-mesenchymal transition is not required for lung metastasis but contributes to chemoresistance. Nature 2015, 527, 472-476. [CrossRef] [PubMed]

130. Zheng, X.; Carstens, J.L.; Kim, J.; Scheible, M.; Kaye, J.; Sugimoto, H.; Wu, C.-C.; LeBleu, V.S.; Kalluri, R. Epithelial-to-mesenchymal transition is dispensable for metastasis but induces chemoresistance in pancreatic cancer. Nature 2015, 527, 525-530. [CrossRef] [PubMed]

131. Wang, H.; Zhang, G.; Zhang, H.; Zhang, F.; Zhou, B.; Ning, F.; Wang, H.-S.; Cai, S.-H.; Du, J. Acquisition of epithelial-mesenchymal transition phenotype and cancer stem cell-like properties in cisplatin-resistant lung cancer cells through AKT/ $\beta$-catenin/Snail signaling pathway. Eur. J. Pharmacol. 2014, 723, 156-166. [CrossRef] [PubMed]

(C) 2018 by the authors. Licensee MDPI, Basel, Switzerland. This article is an open access article distributed under the terms and conditions of the Creative Commons Attribution (CC BY) license (http:/ / creativecommons.org/licenses/by/4.0/). 